\title{
Preparation of Calcium Aluminosilicate Catalyst Foams from Eggshells and Polyurethane Template
}

\author{
La-Orngdow Mulsow and Nuchnapa Tangboriboon \\ Department of Materials Engineering, Faculty of Engineering, Kasetsart University, Bangkok 10900, Thailand
}

Received: October 02, 2012 / Accepted: November 03, 2012 / Published: February 25, 2013.

\begin{abstract}
This research aims to form polymer matrix composites (PMCs) between calcium aluminosilicate $\left(\mathrm{CaNaAlSi}_{2} \mathrm{O}_{7}\right)$ as a dispersed phase made from eggshells as the raw material via the sol-gel process and polyurethane foam (PU) as a matrix. The received PMCs samples were characterized phase formation by X-ray diffraction (XRD), microstructure by scanning electron microscopy, pore size and specific surface area by brunauer-emmett-teller (BET), mechanical properties by compression test, the functional groups by the Fourier transform infrared spectroscopy (FTIR), and the endothermic-exothermic reaction by differential thermal analysis (DTA). The $\mathrm{CaNaAlSi}_{2} \mathrm{O}_{7}$ acted as a dispersant in the polyurethane (PU) matrix, (PMCs). The best composition of composite materials is adding $10 \mathrm{vol} \% \mathrm{CaNaAlSi}_{2} \mathrm{O}_{7}$ into $\mathrm{PU}$ matrix. The average particle size of $\mathrm{CaNaAlSi}_{2} \mathrm{O}_{7}$ is approximately 10 $\mu \mathrm{m}$, non-agglomeration, and good dispersion in the entire volume of PU foam. The composite foam cells are well ordered and uniform in size and shape. The true density, elastic modulus and compressive strength of $\mathrm{CaNaAlSi}_{2} \mathrm{O}_{7} / \mathrm{PU}$ composites are 1.47 $\mathrm{g} / \mathrm{cm}^{3}, 0.0327 \mathrm{Kgf} / \mathrm{mm}^{2}$, and $0.0188 \mathrm{Kgf} / \mathrm{mm}^{2}$, respectively. The $\mathrm{CaNaAlSi}_{2} \mathrm{O}_{7} / \mathrm{PU}$ composites are semi-crystalline phase formation between tetragonal phase formations of $\mathrm{CaNaAlSi}_{2} \mathrm{O}_{7}$ and amorphous phase formation of PU.
\end{abstract}

Key words: Polymer matrix composites, eggshells, calcium aluminosilicate, catalyst, specific surface area.

\section{Introduction}

Over 200 years ago, a Swedish scientist discovered the first of a group crystalline microporous alumino silicate known as zeolite; zeolite derived from Greek word "Zeo" which means boil and "Lithos" means stone [1]. Zeolite consists of open cells, three dimensional framework of tetrahedral $\mathrm{AlO}_{4}{ }^{-}$and $\mathrm{SiO}_{4}{ }^{-}$ units linked through shared oxygen molecules, crystalline microporous and aluminosilicate minerals. Due to their properties that have size and shape selectivity, so its applications can be used in ion-exchange, purification, desiccant or adsorbent, and as a catalyst. The catalysts are quite important in chemical, petrochemical, and oil refining industries.

The calcium sodium aluminosilicate is one kind of zeolites which can be synthesized from many methods

Corresponding author: Nuchnapa Tangboriboon, Ph.D., assistant professor, research fields: composites (PMCs and CMCs), dielectric ceramics. E-mail: fengnnpt@ku.ac.th. such as electrostatic deposition, sol-gel process [2], mixed matrix membranes (MMM) as a promising morphology for gas separation and as a polymer matrix composite, for example, separation of xylene mixtures using polyurethane-zeolite composite membranes [3]. Because polyurethane (PU) has many good properties such as moisture resistance, high shear strength, excellent sound absorption, vibration resistance, and oscillation environment tolerance [4], several researches have used their benefit with homogeneous pore cells in order to improve their researches. The present study is using polyurethane (PU) foams as a matrix for making catalyst composite foams.

This research aims to produce catalyst composite foams between calcium sodium aluminosilicate $\left(\mathrm{CaNaAlSi}_{2} \mathrm{O}_{7}\right)$ as a dispersed phase made from eggshells as the raw material via the sol-gel process and polyurethane foam (PU) as a matrix. The constituent of eggshells contained $1 \mathrm{wt} \%$ of magnesium carbonate, $4 \mathrm{wt} \%$ of calcium phosphate 
and organic matter, and mainly $94 \mathrm{wt} \%$ of calcium carbonate. The eggshell is an important source of calcium oxide as a raw material to prepare the catalyst powder [5].

\section{Experiments}

\subsection{Calcium Chloride Solution Preparation}

Calcium oxide $(\mathrm{CaO})$ was prepared from eggshells by the following steps, washed with tap water and dried at room temperature, crushed and calcined under atmospheric pressure at $900{ }^{\circ} \mathrm{C}$ for $1 \mathrm{~h}$ with a heating rate of $10^{\circ} \mathrm{C} / \mathrm{min}$, then $0.5 \mathrm{~g}$ of air cooled $\mathrm{CaO}$ powder was dissolved in $20 \mathrm{~mL}$ of $1 \mathrm{M} \mathrm{HCl}$ (Analytical Reagent, AR, Lab-Scan Co., Ltd., Thailand) to obtain the $\mathrm{CaCl}_{2}$ solution [2].

\subsection{Sodium Aluminosilicate Solution Preparation}

Sodium aluminosilicate solution was obtained by mixing $0.8 \mathrm{~g}$ of fumed silica powder $\left(\mathrm{SiO}_{2}\right.$, WACKER Chemie, AG, Germany), $5.0 \mathrm{~g}$ of precipitated sodium aluminosilicate (United Silica, Siam Ltd, Thailand), and $1.0 \mathrm{~g}$ of sodium hydroxide $(\mathrm{NaOH}$, Molecule $\mathrm{Co}$., Ltd., Thailand) with $20 \mathrm{~mL}$ distillated water [2].

\subsection{Synthesis of Calcium Sodium Aluminosilicate}

The calcium sodium aluminosilicate $\left(\mathrm{CaNaAlSi} \mathrm{O}_{2} \mathrm{O}_{7}\right)$ was obtained by pouring the mixture solution of 2.1 into the mixture solution of 2.2 stirred then left at room temperature for $24 \mathrm{~h}$, via the sol-gel process [2]. The gel sample was dried at $110{ }^{\circ} \mathrm{C}$ for $24 \mathrm{~h}$ (dried gel at $110{ }^{\circ} \mathrm{C}$ ) and calcined the dried gel at $300{ }^{\circ} \mathrm{C}$ for $1 \mathrm{~h}$ (catalyst powder at $300{ }^{\circ} \mathrm{C}$ ) to obtain $\mathrm{CaNaAlSi}_{2} \mathrm{O}_{7}$ powder.

\section{$2.4 \mathrm{CaNaAlSi}_{2} \mathrm{O}_{7}-\mathrm{PU}$ Catalyst Foams}

PMCs preparation was prepared by using polyurethane foams (PU) as a template (DALTOPED ${ }^{\circledR F F} 45804$ and SUPRASEC ${ }^{2} 2749$ from Huntsman (Thailand)). The FF 45804 is polyol and the SUPRASEC 2749 is di-isocyanate used as pre-polymer. The weight ratio between FF 45804 and
SUPRASEC 2749 is 100:98. The PMCs were prepared by stirring the FF 45804 with a speed of 1,200 rpm for 3 min then added 10 vol\% of catalyst gel into the FF 45804, after that adding the SUPRASEC 2749 rapidly into the mixture. The mixture stirred uniformly until to complete exothermic reaction to obtain the catalyst foams.

\section{Results and Discussion}

The thermal stability of catalyst and PU composite foams was determined by the differential thermal analysis (DTA, Perkins-Elmer TAC7/DX, DTA7, USA) under a nitrogen atmosphere as shown in Fig. 1. The samples were heated from $30{ }^{\circ} \mathrm{C}$ to $950{ }^{\circ} \mathrm{C}$ with a heating rate $10{ }^{\circ} \mathrm{C} / \mathrm{min}$. The result shows an exothermic reaction of $\mathrm{PU}$ foams started to degrade from $530{ }^{\circ} \mathrm{C}$ to $650{ }^{\circ} \mathrm{C}$ as shown in Fig. 1a. Furthermore, the catalyst-composite foams added 10 vol $\%$ catalyst powder (calcined at $300{ }^{\circ} \mathrm{C}$ ) have an endothermic peak at $790{ }^{\circ} \mathrm{C}$ and onset at $786{ }^{\circ} \mathrm{C}$ due to re-crystalline of catalyst gel in $\mathrm{PU}$ foam matrix as shown in Fig. 1b.

The data of true density values of dried gel at $110^{\circ} \mathrm{C}$, catalyst powder (dried gel calcined at $300{ }^{\circ} \mathrm{C}$ ), pure $\mathrm{PU}$ foams, and PU foams added 10 vol $\%$ catalyst powder (dried gel and calcined at $300{ }^{\circ} \mathrm{C}$ ) were analyzed by the gas pycnometer, as shown in Table 1.

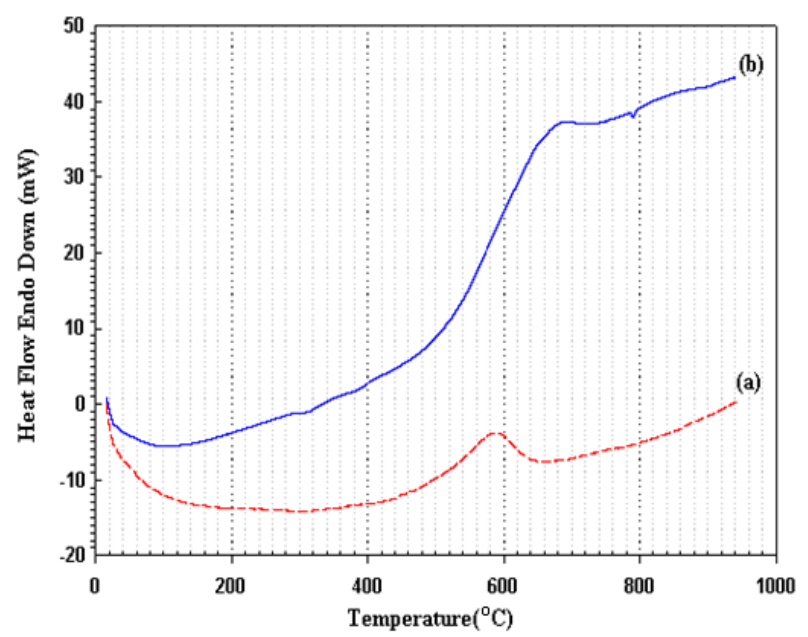

Fig. 1 Differential thermal analysis (DTA) of (a) PU foams and (b) PU foams added $10 \%$ vol of catalyst powder (dried gel calcined at $300{ }^{\circ} \mathrm{C}$ ). 
Table 1 True density values.

\begin{tabular}{ll}
\hline Sample names & True density $\left(\mathrm{g} / \mathrm{cm}^{3}\right)$ \\
\hline Catalyst dried gel at $110{ }^{\circ} \mathrm{C}$ & 1.90 \\
Catalyst powder (dried gel and calcined at $\left.300{ }^{\circ} \mathrm{C}\right)$ & 1.96 \\
Pure PU foams & 1.13 \\
PU foams added 10 vol\% catalyst powder (dried gel and calcined at $\left.300{ }^{\circ} \mathrm{C}\right)$ & 1.47 \\
\hline
\end{tabular}

Table 2 BET analysis of catalyst samples.

\begin{tabular}{llll}
\hline Sample codes & Specific surface area $\left(\mathrm{m}^{2} / \mathrm{g}\right)$ & Total pore volume $\left(\mathrm{cm}^{3} / \mathrm{g}\right)$ & Average pore diameter $(\AA)$ \\
\hline $\begin{array}{l}\text { Catalyst dried gel at } 110^{\circ} \mathrm{C} \\
\begin{array}{l}\text { Catalyst powder } \\
\text { (dried gel and calcined at } 300^{\circ} \mathrm{C}\end{array}\end{array}$ & 37.91 & 0.2917 & 307.8 \\
\hline
\end{tabular}

Adding 10 vol $\%$ catalyst powder (dried gel and calcined at $300{ }^{\circ} \mathrm{C}$ ) into pure PU foams can increase the true density values of composite foams from 1.13 to $1.47 \mathrm{~g} / \mathrm{cc}$. The data of specific surface area, total pore volume, and average pore diameter of dried gel and catalyst powder were analyzed as tabulated in Table 2 . The catalyst powder (dried gel and calcined at $300{ }^{\circ} \mathrm{C}$ ) exhibited surface area, pore volume and pore diameter values higher than the data values of dried gel at $110^{\circ} \mathrm{C}$ because internal voids in the material caused by generating of carbon dioxide $\left(\mathrm{CO}_{2}\right)$. Therefore, the catalyst powder has high values of specific surface area, pore volume, and pore diameter.

The XRD peak pattern of eggshells is consistent with the International Center for Diffraction Data (JCPDS) number of 01-085-1108 expressed $2 \theta$ and (hkl) values equal to 29.47 (104), 36.04 (110), 39.49 (113), 43.24 (2302), 47.69 (018), 48.62 (116) and 48.62 (122), indicating the rhombohedral phase formation of calcium carbonate $\left(\mathrm{CaCO}_{3}\right)$ as shown in Fig. 2a.

Fig. $2 \mathrm{~b}$ shows a peak pattern of $\mathrm{CaO}$, consistent with the JCPDS number of 00-037-1497 at $2 \theta$ and (hkl) equal to 32.61 (111), 37.35 (200), 53.86 (220), 64.15 (311), 67.38 (222) and 79.67 (400) indicating the cubic phase formation. Furthermore, both Figs. $2 \mathrm{c}$ and $2 \mathrm{f}$ demonstrated peak patterns of dried gel at $110{ }^{\circ} \mathrm{C}$ and catalyst powder (dried gel and calcined at $300{ }^{\circ} \mathrm{C}$ ) consistent with the JCPDS numbers of 01-076-0479 and 01-071-2066 at $2 \theta$ and (hkl) equal to 31.81 (211), 45.43 (220), 56.45 (222), 29.31 (201), 68.71 (521), and 75.26 (420), indicating the tetragonal phase formation of calcium sodium aluminosilicate.

Fig. 3 shows the XRD peak pattern comparison between pure PU foams and catalyst composite foams. The step scan were used to pre sent time at $1 \mathrm{~s}$ with $2 \theta$ $=5^{\circ}-80^{\circ}$. The XRD peak patterns of pure PU foams and catalyst composite foams exhibited amorphous regions, so the step scan measured in the range of $2 \theta=$ $5^{\circ}-80^{\circ}$. However, the XRD peak patterns of $\mathrm{CaNaAlSi}_{2} \mathrm{O}_{7}$ powder show crystalline phase in the range of $2 \theta$ equal to $25^{\circ}-35^{\circ}$ as shown in Fig. 4. The peak patterns of Figs. $4 \mathrm{~b}-4 \mathrm{e}$ were demonstrated at $2 \theta$ about $32^{\circ}$ which indicated the tetragonal formation of calcium sodium aluminosilicate.

Fig. 5a shows the FT-IR (Perkin Elmer, Spectrum one) spectrum of $\mathrm{CaO}$ prepared from eggshells calcination.

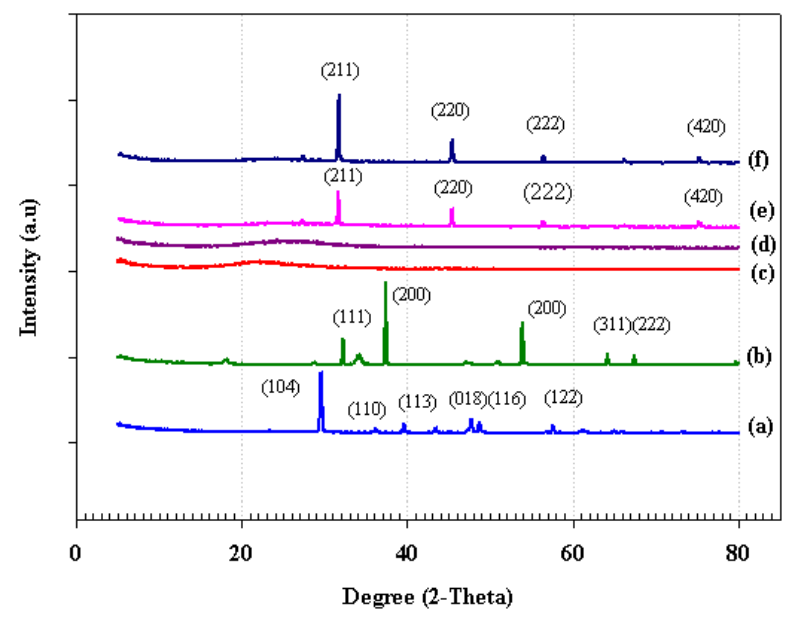

Fig. 2 X-ray diffraction (XRD) patterns comparison of (a) eggshells, (b) $\mathrm{CaO}$, (c) fumed $\mathrm{SiO}_{2}$, (d) aluminosilicate, (e) dried gel at $110{ }^{\circ} \mathrm{C}$, and (f) catalyst powder (dried gel and calcined at $300{ }^{\circ} \mathrm{C}$ ). 


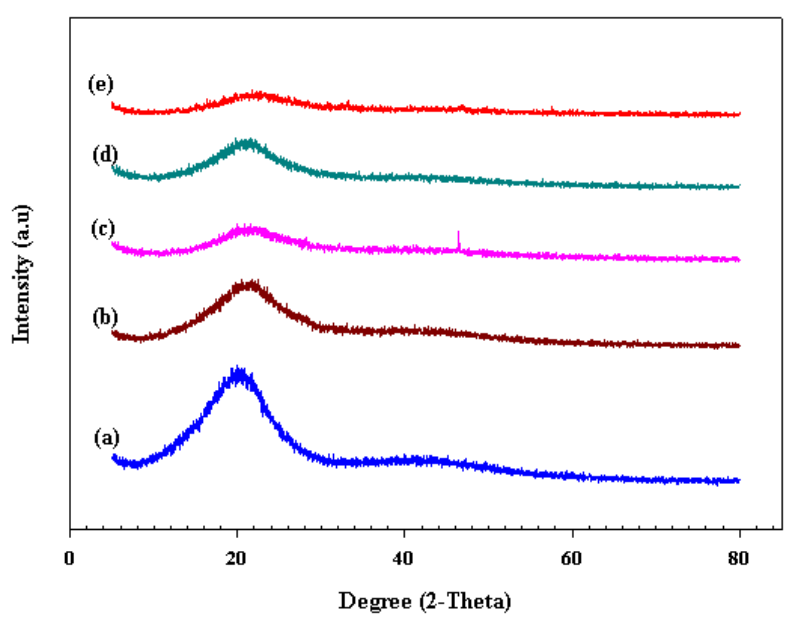

Fig. 3 XRD patterns comparison of (a) pure PU foams, (b) PU foams added 10 vol \% catalyst dried gel $110{ }^{\circ} \mathrm{C}$, (c) PU foams added 20 vol\% catalyst dried gel at $110{ }^{\circ} \mathrm{C}$, (d) PU foams added 10 vol\% catalyst powder (dried gel calcined at $300{ }^{\circ} \mathrm{C}$ ), and (e) PU foams added 20 vol\% catalyst powder (dried gel and calcined at $300^{\circ} \mathrm{C}$ ).

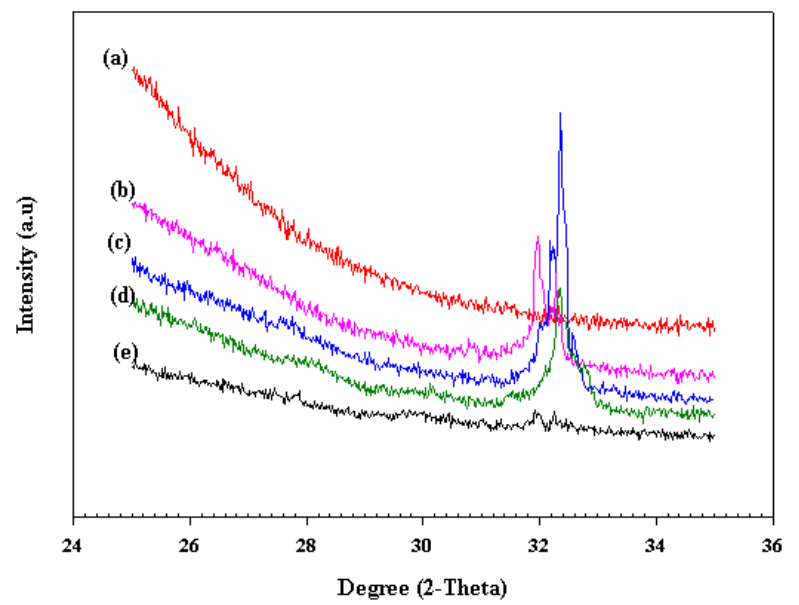

Fig. 4 XRD patterns comparison of (a) pure PU foams, (b) PU foams added 10 vol\% catalyst dried gel at $110{ }^{\circ} \mathrm{C}$, (c) PU foams added 20 vol\% catalyst dried gel at $110{ }^{\circ} \mathrm{C}$, (d) PU foams added 10 vol\% catalyst powder (dried gel and calcined at $300{ }^{\circ} \mathrm{C}$ ), and (e) PU foams added 20 vol\% catalyst powder (dried gel and calcined at $300^{\circ} \mathrm{C}$ ).

The wave number of peak at $3,642.13 \mathrm{~cm}^{-1}$ belongs to $\mathrm{v}-\mathrm{OH}$ of $\mathrm{Ca}(\mathrm{OH})_{2}$ due to moisture absorption of $\mathrm{CaO}$. The broad band peak occurs around $1,440.33 \mathrm{~cm}^{-1}$ corresponding to the Ca-O. Figs. $5 \mathrm{~b}$ and $5 \mathrm{c}$ are the FTIR spectra of catalyst which dried gel at $110{ }^{\circ} \mathrm{C}$, and catalyst powder (dried gel and calcined at $300^{\circ} \mathrm{C}$ ) show at 500-550 $\mathrm{cm}^{-1}$ indicating Al-O-C, Si-O-Al, Si-O, and $\mathrm{Si}-\mathrm{O}-\mathrm{Si}$ bonding consistent with the data reported [2].

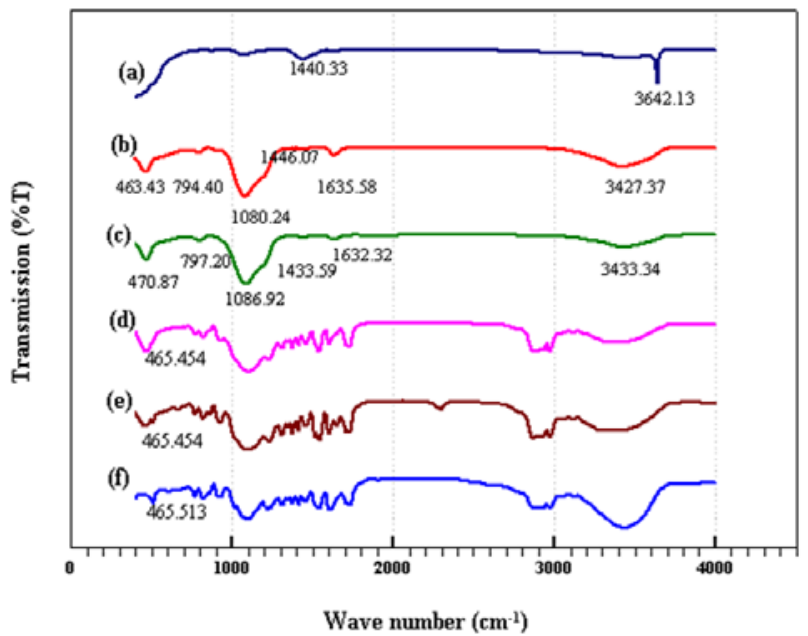

Fig. 5 FTIR spectra of (a) $\mathrm{CaO}$, (b) catalyst dried gel at $110{ }^{\circ} \mathrm{C}$, (c) catalyst powder (dried gel and calcined at $300{ }^{\circ} \mathrm{C}$ ), (d) PU foams added 10 vol\% catalyst dried gel at $110{ }^{\circ} \mathrm{C}$, (e) PU foams added 10 vol\% catalyst powder (dried gel and calcined at $300^{\circ} \mathrm{C}$ ), and (f) pure $\mathrm{PU}$ foams.

In addition, the FTIR spectra at 794.40, and 1,446.04 $\mathrm{cm}^{-1}$ show the characteristics of the $\beta-\mathrm{Ca}-\mathrm{O}-\mathrm{Si}$, $\mathrm{Ca}-\mathrm{O}-\mathrm{Si}$, and strong $\mathrm{C}=\mathrm{O}$ vibration, respectively, which indicated the $\mathrm{CaNaAlSi}_{2} \mathrm{O}_{7}$.

Figs. 5d, 5e and 5f show the FTIR spectra comparison of PU foams added $10 \mathrm{vol} \%$ catalyst dried gel at $110{ }^{\circ} \mathrm{C}$, PU foams added $10 \mathrm{vol} \%$ catalyst powder (dried gel and calcined at $300^{\circ} \mathrm{C}$ ), and pure PU foams.

The PU foams added 10 vol\% catalyst dried gel at $110^{\circ} \mathrm{C}$ show peak positions at 470.89 and $797.20 \mathrm{~cm}^{-1}$, same as the peak positions of the PU foams added 10 vol $\%$ catalyst powder (dried gel and calcined at $300{ }^{\circ} \mathrm{C}$ ) at 463.43 and $794.40 \mathrm{~cm}^{-1}$ corresponding to the characteristics of $\beta-\mathrm{Ca}-\mathrm{O}-\mathrm{Si}$ and $\mathrm{Ca}-\mathrm{O}-\mathrm{Si}$, respectively. The FTIR spectra of the pure PU foams acted as a matrix whereas the calcium sodium aluminosilicate $\left(\mathrm{CaNaAlSi}_{2} \mathrm{O}_{7}\right)$ acted as the dispersed phase for making catalyst composite foams. It is found that the segmented structure of PU no major change the properties and the structure of $\mathrm{CaNaAlSi}{ }_{2} \mathrm{O}_{7}$.

The FTIR spectra of the pure polyurethane foams prepared from the FF 45804 and the SUPRASEC 2749 are shown in Fig. 5f. This spectrum indicates peak positions belonging to polyurethanes at $3,437.71 \mathrm{~cm}^{-1}$ 
consistent with $-\mathrm{N}-\mathrm{H}$ stretching vibration of urethane groups $\left(3,200-3,450 \mathrm{~cm}^{-1}\right)[4]$. The broad band peak at 2,800-3,000 $\mathrm{cm}^{-1}$ corresponds to $-\mathrm{C}-\mathrm{H}$ stretching [6]. They do not show the peak position at 2,250-2,270 $\mathrm{cm}^{-1}$ consistent with the characteristic of isocyanate $(-\mathrm{N}=\mathrm{C}=\mathrm{O})$ group because of polymerization $[6,8]$. The $-\mathrm{C}=\mathrm{O}$ stretching of the urethane carbonyl peak at $1,712.90$ and $1,730.79 \mathrm{~cm}^{-1}$ are observed and reported at $1,702-1,737 \mathrm{~cm}^{-1}$ [7]. The peak at $1,613.45 \mathrm{~cm}^{-1}$ indicates the carbonyl vibration $(-\mathrm{C}=\mathrm{O})$ reported at $1,630-1,637 \mathrm{~cm}^{-1}[6,8]$ while $-\mathrm{NH}$ bending is identified peak at $1,512.21 \mathrm{~cm}^{-1}$. Also, the peak position at $1541.65 \mathrm{~cm}^{-1}$ originates from the coupling of $-\mathrm{CN}$ stretching and -NH bending [9]. The FTIR peaks observed between 1,400 and $1,480 \mathrm{~cm}^{-1}$ (in this work occurred at $1,414.57$ and $1,453 \mathrm{~cm}^{-1}$ ) are attributed to $-\mathrm{CH}_{2}$ scissoring vibrations. The small peaks at 1,345.96 and 1,374.99 are connected to the wagging vibrations of methylene groups, whereas the peak at 1,310.32 $\mathrm{cm}^{-1}$ is assigned to $-\mathrm{CH}_{2}$ twisting. The FTIR spectra exhibit the characteristic peak at $1,000-1,400 \mathrm{~cm}^{-1}$ of $\mathrm{C}-\mathrm{N}$ and C-O stretching. The presence of the FTIR peaks belongs to polyurethane foams.

Fig. 6 shows the SEM photographs analyzed by the scanning electron microscope (SEM) (Philips, XC, Netherland) of pure PU foams and pure PU foams added with 10 vol $\%$ catalyst powder (dried gel and calcined at $300{ }^{\circ} \mathrm{C}$ ). The cell edges and cell walls of pure PU foams are distinctly visible with almost uniform cell structures throughout as shown in Figs. 6a, $6 \mathrm{~b}$ and 6c. Cell size measured by SEM is approximately 200-250 $\mu \mathrm{m}$. The samples added with 10 vol\% catalyst powder (dried gel and calcined at $30{ }^{\circ} \mathrm{C}$ ) are shown in Figs $6 \mathrm{~d}, 6 \mathrm{e}$, and 6 f. The $15 \mathrm{vol} \%$, $20 \mathrm{vol} \%, 30 \mathrm{vol} \%$, and $50 \mathrm{vol} \%$ of catalyst powder (dried gel and calcined at $300{ }^{\circ} \mathrm{C}$ ) were added into PU foams. The excess volume percentage of catalyst added into PU foams is not good for making catalyst composite foam formation due to the agglomeration of catalyst particles within the interconnecting cells of PU foams. Therefore, the best composition of composite materials is adding $10 \mathrm{vol} \% \mathrm{CaNaAlSi}_{2} \mathrm{O}_{7}$ into $\mathrm{PU}$ matrix with uniform structure and non-agglomeration of catalyst powder. The composite foam cells still are well ordered and uniform in size and shape. However, open cells of the composite foam seem smaller than that of pure PU foams. According to the SEM image results of catalyst composite foams which added 10 vol\% catalyst dried gel at $110{ }^{\circ} \mathrm{C}$ into PU foam matrix are similar SEM micrographs of catalyst composite foams added with $10 \mathrm{vol} \%$ catalyst powder (dried gel and calcined at $300^{\circ} \mathrm{C}$ ) into PU foam matrix.

The compressive strength and elastic modulus of PU foams added $10 \mathrm{vol} \%$ catalyst powder (dried gel and calcined at $300{ }^{\circ} \mathrm{C}$ ) compared to pure PU foams were measured by a compressive testing instrument (Qmat 5.44 M-Series-10 KM) according to ASTM D 695 compression of rigid plastics. The dimensions of are $25.4 \times 25.4 \times 12.7 \mathrm{~mm}^{3}$ and the crosshead speed of compression was set at $1.2 \mathrm{~mm} / \mathrm{min}$. The elastic

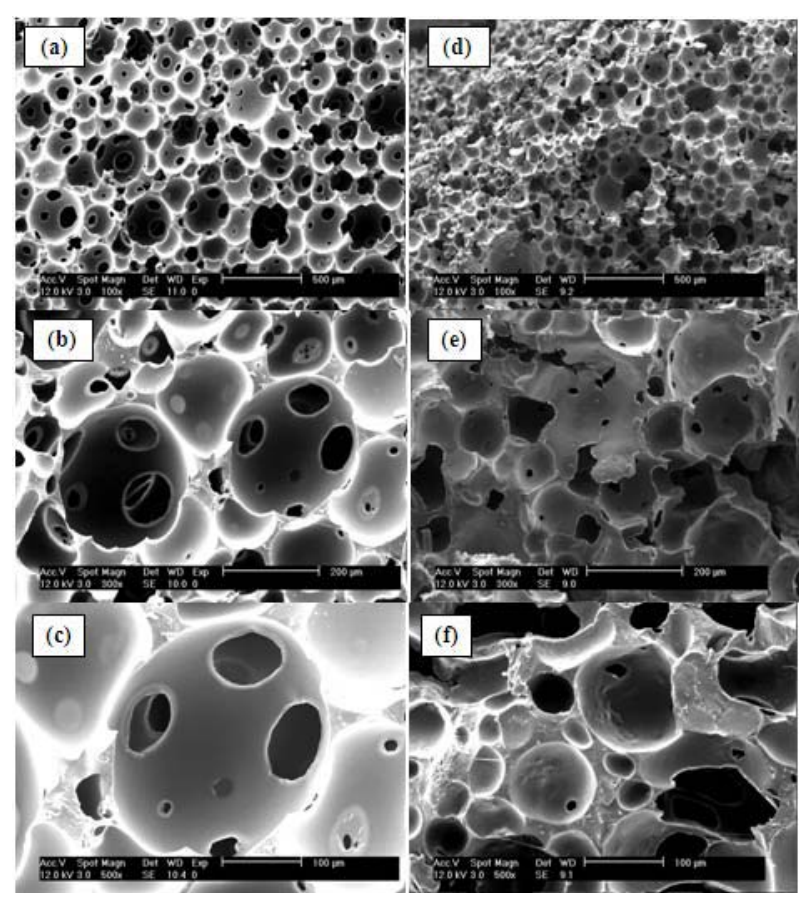

Fig. 6 SEM picture of (a) pure PU foams at $500 \mu \mathrm{m}$, (b) pure PU foams at $200 \mu \mathrm{m}$ (c) pure PU foams at $100 \mu \mathrm{m}$ (d) pure PU foams added 10 vol\% catalyst powder (dried gel and calcined at $300{ }^{\circ} \mathrm{C}$ ) at $500 \mu \mathrm{m}$ (e) pure $\mathrm{PU}$ foams added 10 vol\% catalyst powder (dried gel and calcined at $300{ }^{\circ} \mathrm{C}$ ) at $200 \mu \mathrm{m}$, (f) pure PU foams added $10 \mathrm{vol} \%$ catalyst powder (dried gel and calcined at $300{ }^{\circ} \mathrm{C}$ ) at $100 \mu \mathrm{m}$. 
modulus and compressive strength of the composite foams are $0.0327 \pm 0.0078$ and $0.0188 \pm 0.0017$ $\mathrm{Kgf} / \mathrm{mm}^{2}$, respectively. The elastic modulus and compressive strength of pure PU foams are $0.1162 \pm$ 0.047 and $0.0245 \pm 0.0067 \mathrm{Kgf} / \mathrm{mm}^{2}$, respectively. The mechanical properties (elastic modulus and compressive strength) of catalyst composite foams added catalyst powder (dried gel and calcined at $300{ }^{\circ} \mathrm{C}$ ) are less than that of pure PU foams due to $\mathrm{H}$-bond formation among urethane groups that greatly contributes to the strength and modulus of PU foam, for the reason of catalyst powder (dried gel and calcined at $300{ }^{\circ} \mathrm{C}$ ) may intervene with the H-bond formation and no strong interaction or graft within PU matrix. Therefore, the pure PU foams have high elastic modulus and compressive strength. Furthermore, catalyst composite foams have high specific surface area, thermal resistance, and corrosion resistance useful for using as catalyst composite foams.

\section{Conclusions}

The catalyst foam was successfully made from eggshells as the raw material of calcium sodium aluminosilicate catalyst via the sol-gel process to prepare PMCs. The $\mathrm{CaNaAlSi}_{2} \mathrm{O}_{7} / \mathrm{PU}$ composites have potential as catalyst composite foams in the chemical and petrochemical industries functioned as ion exchange, filter, and desiccant.

\section{Acknowledgments}

The authors would like to thank the Department of Material Engineering at Kasetsart University for using of analytical equipment, the Petroleum and
Petrochemical College, the Scientific and Technological Research Equipment Centre, at Chulalongkorn University for using of analytical equipment, and the Huntsman (Thailand) Ltd., for providing the chemical substance to prepare polyurethane foams.

\section{References}

[1] J.C. Van der waal, H. Van bekkumMolecular sieves, multifunctional microporous materials in organic synthesis, J. Porous. Mat. (1998) 289-303.

[2] T. Nuchnapa, W. Sujita, K. Ruksapong, S. Anuvat, An innovative synthesis of calcium zeolite type a catalysts from eggshells via the sol-gel process, J. Inorg. Organomet. Polym. (2010) 50-60.

[3] M.L. Pinto, J. Pires, A.P. Carvalho, M.B.de Carvalho, J.C. Bordado, Synthesis and regeneration of polyurethane/adsorbent composites and their characterization by adsorption methods, Microporous Mesoporous Mater. 89 (2006) 260-269.

[4] M. Hassan, R. Vijaya, I. Mohammad, Synthesis and mechanical characterization of nanoparticles infused polyurethane foam, J. Shaik Part A 35 (2004) 453-460.

[5] W. Ziku, X. Chunli, L. Baoxin, Application of waste eggshell as low-cost solid catalyst for biodiesel production, J. Bio. Tech. (2009) 2883-2885.

[6] G. Trovati, E. Ap Sanches, S. C. Neto,Y. P. Mascarenhas,G. O. Chierice, Characterization of polyurethane resins by FTIR, TGA, and XRD, J. Appl. Polym. Sci. 115/1(2009) 263-268.

[7] L. Yongshang, L. Richard, Soybean oil-based, aqueous cationic polyurethane dispersions: Synthesis and properties, Progress in Organic Coatings 69 (2010) 31-37.

[8] M.A. Corcuera, L. Rueda, B. Fernandez d'Arlas, A. Arbelaiz, C. Marieta, I. Mondragon, et al., Microstructure and properties of polyurethanes derived from castor oil, Polymer Degradation and Stability 95 (11) (2010) 2175-2184. 